\title{
Utilization of Waste Materials as Adsorbents for Color Removal from Textile Effluents- A Review
}

\author{
Priya $\mathrm{AK}^{*}$ \\ Department of Civil Engineering, KPR Institute of Engineering and Technology, Coimbatore, India
}

Received: January 20, 2018; Published: February 01, 2018

*Corresponding author: Priya AK, Department of Civil Engineering, KPR Institute of Engineering and Technology, Coimbatore- 641407, India, Tel: 8870802844; Email: akpriy@gmail.com

\section{Introduction}

Environmental pollution is the main vital troubles of the society. Growth in farming, energy sources and all hazardous waste producing industries is essential in categorize to execute the requirements and burden of the increasing population. Individual activities for the creation and development of supplies and services can't be extremely blocked as it is desirable by humans for the endurance on world. For the times of yore, creation of dyes and stains was augmented in the populated world. This concern is not only because of textile industry but also from other industries like paper and pulp, leather, food, cosmetics etc. These production industries are main regulars of water and consequently put strong foundation to water pollution. Among these industries textile industries is one of the supreme originators of water pollution owing to huge quantity of water utilized during the process in dyeing plant. For insistence yearly generation of dyes is approximately $7 \times 105$ tonnes worldwide Allen and Koumanova [1]. Without proper treatment if the dyeing effluent is disposed in the water bodies it leads to severe issues to environment as well as to the humans.

Complex chemical components were released from the dye effluents which are more stable and less biodegradable in nature Ramakrishna and Viraraghavan [2]. Concerning 10 to $15 \%$ of the dyes liberated in the effluent are from the dyeing unit USEPA [3]. Synthetic dyes are more complex, stable due to its molecular structure and less degradable. But reactive dyes vary from synthetic dyes due to its covalent bond. Effluent with reactive dyes has the predominant portion of Chemical Oxygen Demand (COD) and color has to be treated properly before discharge into the environment. Existence of color in textile effluent shows that the water has been polluted priya et al. $[4,5]$. The discharge of dyes causes lethal hazard and leads to bioaccumulation also affects the humans through food chain. The ancient and traditional processes for the color removal from textile effluent comprise biological treatment and chemical treatment like coagulation, flocculation, adsorption etc which includes high energy and cost Anjaneyulu [6].

\section{Adsorption}

It is surface processes which adsorb the contaminants on the surface of adsorbent. Popularly activated carbon is used as a adsorbent for color removal in the treatment of textile effluent. During adsorption process, contaminants get removed in the form of a film on the adsorbent surface. For dye removal from textile industry offers huge amount for treatment especially for adsorption process. However huge investment towards non renewable resources ie activated carbon is not economical for developing country. Hence, there is a need identify the cost effective and easily available adsorbent for treating textile effluent. Crini [7] analyzed non-conventional and low-cost adsorbents for color removal from textile industry effluent. Many studies has been focused towards economical and competent bioadsorbent which was prepared from different types of naturally available materials. Biosorption is a possession of inert and dead biomass to adsorb dissimilar contaminants by inactive binding to dead microbes (bacteria, fungi and algae) and other biomass from aqueous solutions $\mathrm{Ma}$ and Tobin [8]. Biosorption process is conflicting to bioaccumulation by organisms and the mainly extensive method of bioremediation is biosorption. In recent years this technique becomes more accepted for wastewater treatment due to its competence in the removal of color. Dye adsorption is a consequence of two mechanisms (adsorption and ion exchange) and is influenced by several aspects such as contact time, adsorbent interaction, adsorbent's surface area, particle size, temperature and $\mathrm{pH}$.

\section{Agricultural Residue as Adsorbent}

Nearly 400 million tones of agricultural waste is produced every year in India Raghuvanshi et al. [9]. Some of the residues which generated every year comprise of tea waste, coir pith, saw dust, bagasse, tendu leaf refuse, rice husk etc. Many research work has been carried out for color removal from textile industry effluents using agricultural residues as adsorbent. Various agricultural products and lingo-cellulosic by-products were investigated for 
dye removal from aqueous solutions. The studies includes dye adsorption onto jute stick Panda et al. [10], rice bran Hashemian et al. [11], palm kernel fibre Ofomaja [12], peanut hull Renmin et al. [13]tree fern Ho et al. [14], neem leaf powder Bhattacharyya and Sharma [15] and orange peel Namasivayam et al. [16] have been reported. Majority of agricultural wastes and by-products were discarded illogically as soil amendment, landfill or burned resulting in resource loss and environmental pollution Gong et al. [17].

\section{Bidi Leaf Refuse}

The bidi producing industry in India, makes wounding of tendu (Diospyros melanoxylon) leaves as refuse which pollute the discarding sites and generate solid waste disposal crisis. Tendu leaf waste from bidi industry which is chemically treated to get activated biomass and it is examined for its efficiency in removal of the hexavalent chromium from aqueous solution. Moreover, cellulosic wastes that are existing in bulk and round the year are of interest for search of effective and selective adsorbent priya et al. [5]. In India, bidi rolling industry generates cuttings of tendu (Diospyros melanoxylon) leaf as waste, which has no economic value and creates solid waste disposal problem. Therefore, there was a need to valorize this zero-cost tendu waste, available in large quantities round the year throughout India.

\section{Rice Husk}

Experiments were conducted to study the use of rice husk and activated carbon for phenol removal by Kermani et.al. [18] The rice husk ash was prepared at three different temperatutes i.e.300, 400 and 500 0C. The experiments were carried out to examine the effect of various parameters like initial concentration, contact time $\mathrm{pH}$, adsorbent dose on the adsorption capacity. 5 hours contact time was reported for $10 \mathrm{mg} / \mathrm{l}$ phenol concentration for maximum removal. Activated carbon followed Freundlich isotherm while rice hush ash followed the Langmuir isotherm. The adsorbent dose of 1 gram per liter, initial concentration of $10 \mathrm{mg} / \mathrm{l}$ and $\mathrm{pH}$ values of 5 , were the optimum parameters for dye removal.

\section{Egg shell}

Egg shell is largely-crystalline calcium carbonate. The calcium comes partly from the hen's bones and when necessary the hen can mobilize 10 percent of her bone for the purpose.

\section{Conclusion}

In this review, a wide range of non-conventional low- cost adsorbents has been presented. Inexpensive, locally available and effective materials could be used in place of commercial activated carbon for the removal of dyes from textile effluent. Undoubtedly low-cost adsorbents offer a lot of promising benefits for commercial purposes in the future.

\section{References}

1. Allen SJ, Koumanova B (2005) Decolourisation of water/wastewater using adsorption (Review). J University of Chemical Technology and Metallurgy 40(3): 175-192.
2. Ramakrishna KR, Viraraghavan T (1997) Dye Removal Using Low Cost Adsorbents. Wat Sci Tech 36(2-3): 189-196.

3. (1997) USEPA, Profile of Textile Industry (Publication No. EPA/310-R-97-009) US Environmental Protection Agency, Washington, USA, p. 40-41.

4. Priya AK, Nagan S, Nithya M, Priyanka PM, Rajeswari M (2016) Assessment of Tendu Leaf Refuses for the Heavy Metal Removal from Electroplating Effluent. Journal of Pure and Applied Microbiology 10(1): 585-591.

5. Priya AK, Nagan S, Rajeswari M, Nithya M, Priyanka PM, et al. (2016) Rotating biological contactor for the treatment of textile industry wastewater. International journal of advanced engineering technology $7(1): 209-213$.

6. Anjaneyulu Y, Sreedhara Chary N, Samuel Suman Raj D (2005) Decolourization of industrial effuents -available methods and emerging technologies-A review. Reviews in Environmental Science and Bio/ Technology 4(4): 245-273.

7. Crini G (2006) Non-conventional low-cost adsorbents for dye removal: A review. Bioresource Technol 97(9): 1061-1085.

8. Ma W, Tobin JM (2003) Development of multimetal binding model and application to binary metal biosorption onto peat biomass. Water Res 37(16): 3967-3977.

9. Raghuvanshi SP, Singh R, Kaushik CP (2004) Kinetics study of methyene blue bye bioadsorption on baggase. Applied Ecology and Environmental Research 2(2): 35-43.

10. Panda GC, Das SK, Guha AK (2009) Jute stick powder as a potential biomass for the removal of congo red and rhodamine B from their aqueous solution. Journal of Hazardous Materials 164(1): 374-379.

11. Hashemian S, Dadfarnia S, Nateghi MR, Gafoori F (2008) Sorption of acid red 138 from aqueous solutions onto rice bran. African Journal of Biotechnology 7(5): 600-605.

12. Ofomaja AE (2007) Kinetics and mechanism of methylene blue sorption onto palm kernel fibre. Process Biochemistry 42(1): 16-24.

13. Renmin G, Yingzhi S, Jian C, Huijun L, Chao Y (2005) Effect of chemical modification on dye adsorption capacity of peanut hull. Dyes and Pigments 67(3): 175-181.

14. Ho YS, Chiang TH, Hsueh YM (2005) Removal of basic dye from aqueous solution using tree fern as a biosorbent. Process Biochem 40(1): 119124.

15. Bhattacharyya KG, Sharma A (2005) Kinetics and thermodynamics of methylene blue adsorption on neem (Azadirachta indica) leaf powder. Dyes and Pigments 65(1): 51-59.

16. Namasivayam C, Kavitha D (2002) Removal of Congo red from water by adsorption onto activated carbon prepared from coir pith, agricultural solid waste. Dyes Pigments 54(1): 47-58.

17. Gong R, Jin Y, Sun J, Zhong K (2008) Preparation and utilization of rice straw bearing carboxyl groups for removal basic dyes from aqueous solution. Dyes Pigments 76(2): 519-524.

18. Kermani MH, Pourmoghaddas B Bina, Khazai Z (2006) Removal Of Phenol From Aqueous Solution By Rice Husk And Activated Carbom. Pakistan Journal Of Biological Sciebce 9(10): 1905-1910. 
(c) (1) This work is licensed under Creative

Submission Link: http://biomedres.us/submit-manuscript.php

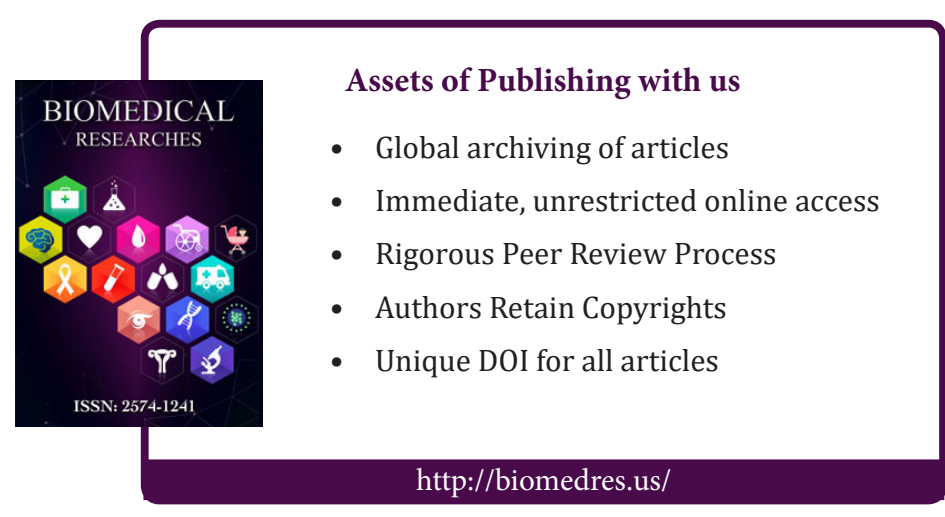

